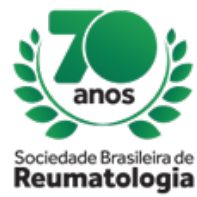

\title{
CATASTROPHIC ANTIPHOSPHOLIPID SYNDROME WITH FAVORABLE OUTCOME
}

Elisa Fernandes de Melo (Universidade de Taubaté, Taubaté, SP, Brasil), Vinicius Verlangieri Soubihe (Universidade de Taubaté, Taubaté, SP, Brasil), Raylane Shellyda de Almeida Anate (Universidade de Taubaté, Taubaté, SP, Brasil), Natália Engler Ravasio (Universidade de Taubaté, Taubaté, SP, Brasil), Laís Helena Bittencourt Ribeiro Soubhia (Universidade de Taubaté, Taubaté, SP, Brasil), Aline Gimenez Guerra (Universidade de Taubaté, Taubaté, SP, Brasil), Larissa Almeida Campos Esteves (Universidade de Taubaté, Taubaté, SP, Brasil), Nathália Faria de Paula (Universidade de Taubaté, Taubaté, SP, Brasil), Fernanda Magalhães de Moraes Lopes (Universidade de Taubaté, Taubaté, SP, Brasil)

\section{BACKGROUND}

Antiphospholipid syndrome (APS) is a systemic autoimmune disease characterized by recurrent arterial or venous thrombosis and / or gestational morbidity and by the presence of antiphospholipid antibodies, and it may present with other vascular manifestations, such as microangiopathy, chronic arteriopathy and catastrophic antiphospholipid syndrome (CAPS). The last corresponds to $1 \%$ of patients with APS, manifesting as generalized thrombosis (3 or more organs).

\section{CASE REPORT}

Patient 30 years old, with dyspnea, chest pain and cough for a month. He searched the emergency room where treatment for pulmonary disease was started, but he presented lowering of the level of consciousness accompanied by hemiplegia in right dimidia and aphasia. Associated with the condition, the patient had calf stuffing, edema and increased temperature in the lower right limb. At the CT scan, presence of left bordered frontotemporal hypodensity on the left associated with hyperdensities in the adjacent cortical grooves suggesting subarachnoid hemorrhage and in Doppler of lower right limb, presence of iliacofemoropopliteal vein thrombosis; echocardiogram showed no changes. Due to the clinical picture, anticoagulation was initiated and an investigation was performed for autoimmune diseases and the presence of antinuclear factor (ANA) with dense fine nuclear pattern 1: 320 and in the investigation of Antiphospholipid Antibody Syndrome, presence of a positive lupus anticoagulant. During hospitalization, the patient evolved with sudden dyspnea and requested angiotomography, which evidenced pulmonary embolism (PE) and splenic infarction (figure 1). Patient progressed well with improvement of the overall picture, but aphasic.

\section{CONCLUSION}

The clinical picture of generalized thrombosis of multiple organs accompanied by insufficiency or failure of the same, in association with antiphospholipid antibodies, is called "catastrophic antiphospholipid syndrome" or Asherson's syndrome. This is a variant of APS, which may occur in patients without this diagnosis or even during the course of the primary and/or secondary syndrome, even with anticoagulant therapy. Patients present mainly small vessel occlusions and clinical manifestations depend on the affected organs. Unchaining factors can be observed in half of the cases and, despite the treatments, their mortality is still high. 